\title{
PONDOK PESANTREN SALAF SEBAGAI MODEL PENDIDIKAN DERADIKALISASI TERORISME
}

\author{
Nur Kholis \\ Sekolah Tinggi Agama Islam Darussalam Lampung \\ Jl. Cendrawasih No. 01, Lampung Timur, 34196, Indonesia \\ E-mail: suarasaljuq@gmail.com
}

\begin{tabular}{l|l|l}
\hline Received: & Revised: & Approved: \\
16/03/2017 & $22 / 06 / 2017$ & $23 / 06 / 2017$ \\
\hline
\end{tabular}

\section{Abstrak}

Tulisan ini mendiskusikan tentang pondok pesantren salaf sebagai model pendidikan deradikalisasi terorisme. Secara garis besar tindakan radikal dan teror ini bersumber dari ideologi yang salah namun dianggap benar dan cara memahami Al-Qur'an yang hanya dilakukan secara tekstual saja. Sebenarnya pemerintah diseluruh dunia telah melakukan upaya untuk memberantas aksi tindakan keji ini dengan berbagai macam bentuk, namun kebanyakan hanya bersifat militer saja, sehingga hal ini hanya bersifat menghapus para pelaku tindakan teror dan radikal tanpa menghapus penyebab utama munculnya tindakan radikal dan teror ini. Sehingga diperlukan upaya deradikalisasi yang cukup ampuh untuk menanggulangi hal tersebut salah satunya dapat dilakukan dengan model pendidikan pondok pesantren salaf yang dikenal dengan tradisi-tradisi humanisnya dan pembekalan ilmu-ilmu yang relevan untuk memahami ayat-ayat Al-Qur'an, agar terhindar dari kesalahan dalam memahami ayat Al-Qur'an, Sehingga 
mampu memberikan tameng yang kuat untuk tidak terjerumus kedalam lembah aksi-aksi radikal dan teror.

Kata kunci: pesantren salaf, deradikalisasi, dan terorisme

\section{Abstract}

This article discusses about salaf pesantren as a model of terrorism deradicalisation education. Broadly the act of radical and terror comes from a wrong ideology but it is considered as a correct ideology and the way in comprehending the Qur'an which is only done in a textual way. In fact, the governments around the world have attempted to combat this cruel action in various forms, yet mostly only military, so this action only removes the perpetrators without removing the main cause of these radical and terror acts. So it is necessary to conduct deradicalisation to cope this problem and one of them can be done with the model of salaf pesantren which is well known with the humanist traditions and the provision of relevant sciences to understand the verses of the Qur'an, in order to avoid the mistake in interpreting the verses of the Qur'an, hence it can provide a strong shield in order not to be trapped to the radical and terror actions.

Keywords: salaf pesantren, deradicalisation, and terrorism

\section{A. Pendahuluan}

Maraknya aksi terror yang terjadi saat ini, benar-benar membuat semua pihak merasa was-was terhadap keselamatannya masing-masing. Namun yang paling mengganjal dalam benak kita ialah para pelaku terorisme ini kebanyakan adalah orang-orang muslim, padahal jika kita menengok pada kilas sejarah Islam, Rasulullah Muhammad SAW dikenal sebagai uswatun hasanah ataupun suri tauladan yang mulia. ${ }^{1}$ Kemudian juga

1 “Qs. Al-Ahzab Ayat 21," n.d. 
disebutkan di dalam kitab Al-Barzanji bahwa Rasulullah memiliki sifat sangat pemalu dan sangat tawadhu', ${ }^{2}$ dan belum pernah disebutkan dalam literatur Islam manapun bahwa baginda Rasulullah SAW memiliki sikap keburukan. Seharusnya dari hal sederhana ini dapat kita analisa bahwa jika sang pembawa ajaran Islam adalah orang yang benarbenar disucikan, maka tentu saja apa yang diajarkannya tidak akan pernah merugikan siapapun. Lantas mengapa justru orang-orang muslimlah yang melakukan perbuatan keji seperti terorisme dan aksi-aksi radikal di belahan dunia ini ? dalam hemat penulis oknum-oknum yang melakukan serangkaian tindakan radikal dan terror ini ialah orangorang yang memahami Al-Qur'an secara tekstual serta menganut ideologi yang salah. Maka tidak mengherankan tatkala oknum-oknum ini dihadapkan dengan ayat-ayat yang perlu kajian mendalam, ${ }^{3}$ mereka justru mengambil kesimpulan secara cepat tanpa menganalisis dengan menggunakan rasional dan keilmuan yang relevan.

Berdasarkan hal tersebut tentunya diperlukan upaya deradikalisasi agama, hal ini dilakukan untuk menanggulangi radikalisme dan terorisme yang sering mengatasnamakan agama. Pendekatan agama ini sangat penting untuk memberikan pemahaman agama yang tepat, kontekstual dan menjujung tinggi nilai-nilai kemanusiaan dalam beragama kepada masyarakat. Pemahaman kontekstual dan pembumian nilai humanitas agama akan melahirkan aksi atau implementasi beragama yang jauh dari aksi-aksi kekerasan, radikalisme dan terorisme. Deradikalisasi agama bukan bertujuan untuk menghilangkan ajaran jihad dalam Islam, akan tetapi untuk

2 Syaikh Abdul Karim Alhusaini, Al-Barzanji (Semarang: Karya Toha Putra, 2003), 123.

3 "Contoh Ayat Ini Ialah Surat At Taubah Ayat 5, Ayat 29 dan Al-Maidah Ayat 44," n.d. 
memberikan interpretasi jihad yang kontekstual dan tidak bersifat destruktif. Jihad dalam arti membangun peradaban dan kehidupan yang sejahtera, penuh cinta, kasih sayang dan persaudaraan sesama manusia. Bukan jihad membunuh pihak lain atau mencari kematian dengan mengatasnmakan Tuhan. ${ }^{4}$

Proses deradikalisasi agama akan lebih efektif dan efisien bila dilakukan melalui lembaga pendidikan, baik formal maupun non formal. Salah satu lembaga yang dapat dijadikan sebagai sarana dan wahana deradikalisasi agama adalah Pondok Pesantren Salaf, yang umumnya merupakan jaringan pendidikan yang terkait erat dengan organisasi Nahdhatul Ulama (NU). Fakta sejarah telah membuktikan bahwa pondok pesantren merupakan institusi pendidikan agama Islam yang sangat fungsional. Pesantren mampu memberi jawaban terhadap berbagai permasalahan yang dihadapi masyarakat, khususnya tingkat bawah. Pesantren juga mampu mempertahankan eksistensinya meskipun perubahan zaman berjalan dengan pesat. ${ }^{5}$

Berdasarkan latar belakang di atas tentunya sangat menarik untuk mengkaji peran pondok pesantren salaf dalam mencegah tumbuhnya bibit-bibit ideologi radikal yang menjurus pada tindakan terorisme melalui budaya humanis dan kurikulumnya yang khas.

4 Imam Musthofa, "Pesantren dan deradikalisasi agama," Sarjana Membangun Desa, diakses 14 Januari 2016, http:/ / mushthava.blogspot.co.id/2012/02/ pesantren-danderadikalisasi-agama.html.

${ }^{5}$ Ibid. diakses tanggal 16 Januari 2016 


\section{B. Pembahasan}

1. Sekelumit Makna Radikalisme, Terorisme dan Pondok Pesantren Salaf

Radikalisme memiliki pengertian paham atau aliran yang radikal dalam politik, paham atau aliran yang menginginkan perubahan atau pembaharuan sosial dan politik dengan cara keras dan sikap ekstrim dalam suatu aliran politik. ${ }^{6}$ Radikalisme dalam pengaplikasiannya memiliki konotasi yang berbeda-beda hal ini tergantung ranah objek yang menjadi tujuannya. Radikalisme dalam konteks sosial budaya memiliki makna gerakan sangat gigih dan lantang, berusaha memperjuangkan perbaikan hak-hak sipil dan feminis, yang berhasil mendesak pemerintah melakukan berbagai perubahan mendasar hingga menjadikan demokrasi negara lebih maju. Sedangkan radikalisme dalam konteks politik dikaitkan dengan aliran, paham, ide-ide, atau gerakan dari individuindividu dan kelompok-kelompok yang mendambakan perubahan fundamental atas tatanan politik yang ada dengan cara kekerasan, derastis, dan ekstrim yang disebabkan di dalamnya terdapat klaim absolutism kebenaran yang dipaksakan. ${ }^{7}$

Istilah radikalisme tidak jarang dimaknai berbeda diantara kelompok kepentingan, dalam lingkup kelompok keagamaan, radikalisme merupakan gerakan-gerakan keagamaan yang bersusaha merombak secara total tatanan sosial dan politik yang ada dengan menggunakan jalan

${ }^{6}$ Departemen Pendidikan dan Kebudayaan Balai Pustaka, Kamus Besar Bahasa Indonesia (Jakarta: Balai Pustaka, 1989), 719.

7 Mahrus As'ad, "Radikalisme Islam di Indonesia" (Seminar International on Radicalism in Islamic Perspective : Problem and Solution", STAIN Jurai Siwo Metro, 28 September 2015), 2. 
kekerasan. ${ }^{8}$ Radikalisme agama bertolak dari gerakan politik yang mendasarkan diri pada suatu doktrin keagamaan yang paling fundamental secara penuh dan literal bebas dari kompromi, penjinakan dan reinterprestasi (penafsiran). ${ }^{9}$ Sedangkan dalam studi ilmu sosial radikalisme diartikan sebagai pandangan yang ingin melakukan perubahan yang mendasar sesuai dengan interpretasinya terhadap realitas sosial atau ideologi yang dianutnya. ${ }^{10}$ Berdasarkan telaah arti radikalisme tersebut, radikalisme sesungguhnya merupakan konsep yang netral dan tidak bersifat pejorative (melecehkan). Karena perubahan yang besifat radikal bisa dicapai melalui cara damai dan persuasive, tetapi bisa juga dengan kekerasan. ${ }^{11}$

Berdasarkan paparan di atas dapat kita pahami bahwa radikalisme dapat bermakna positif dan bermakna negatif, akan tetapi pada hakikatnya radikalisme menuntun seseorang, ataupun sebuah kelompok untuk berbuat anarki, jika apa yang mereka inginkan ataupun yang mereka perjuangkan tidak terpenuhi. Hal ini akan sangat berbahaya sekali tatkala gerakan-gerakan radikal ini berubah menjadi gerakan terorisme, dimana gerakan ini memiliki pengertian penggunaan kekerasan untuk menimbulkan ketakutan dalam usaha mencapai suatu tujuan terutama tujuan politik, praktik-praktik tindakan terror. ${ }^{12}$ Dengan demikian

8 A. Rubaidi, Radikalisme Islam, Nahdatul Ulama Masa depan Moderatisme Islam di Indonesia (Yogyakarta: Logung Pustaka, 2007), 33.

9 Azyumardi Azra, "“Memahami Gejala Fundamentalisme: Jurnal Ulumul Qur'an" IV, no. 3 (1993): 5.

10 "Radikalisme Agama di Jabodetabek \& Jawa Barat: Implikasinya terhadap Jaminan Kebebasan Beragama / Berkeyakinan" (Jakarta: Pustaka Masyarakat Stara, 2010), 19.

${ }^{11}$ Ibid

12 Departemen Pendidikan dan Kebudayaan Balai Pustaka, Kamus Besar Bahasa Indonesia, 939. 
menurut hemat penulis tindakan radikal ini tidak dapat dibenarkan, meskipun dengan dasar untuk mencapai tujuan sebuah kelompok dimana cara memperolehnya menggunakan kekerasan.

Selain tindakan radikal, di era moderen ini tindakan terorisme juga sedang naik daun, hal ini dapat dilihat dari kilas sejarah yang masih teringat segar dalam ingatan kita bahwa pada tanggal 12 Oktober 2002 Indonesia menerima serangan bom bunuh diri terbesar dari yang pernah ada. ${ }^{13}$ Kemudian belum lama ini ibu kota Indonesia juga menerima serangan bom bunuh diri tepatnya di sarinah, yang menyebabkan setidaknya tujuh orang tewas, dan melukai 17 orang lainnya. ${ }^{14}$ Syamsul $\mathrm{Ma}^{\prime}$ arif mengatakan bahwa Terorisme ini sejatinya merupakan Radikalisme dalam bentuk tindakan, ${ }^{15}$ artinya hal ini bersumber dari ideologi radikal yang kemudian diimplementasikan dalam bentuk tindakan untuk meraih apa yang mereka kehendaki. Jika melihat fenomena aksi-aksi terorismse yang terjadi di Indonesia maka kita akan menemukan fakta bahwa para pelaku tindakan terror ini melakukan aksinya karena mereka menginginkan Indonesia menerapkan syari'at islam bukan demokrasi yang merupakan hasil produk skuler.

Berdasarkan keterangan tersebut maka dapat disimpulkan bahwa terorisme adalah tindakan yang dapat mengganggu keamanan orang banyak baik jiwa, harta, maupun kemerdekaannya yang dilakukan oleh perorangan, kelompok ataupun negara dan hal ini tentu saja sangat

${ }_{13}$ Bambang Abimanyu, Terror Bom Azhari-Noor Din (Jakarta: Republika, 2006), 83-90.

14 diakses 14 Januari 2016, http://kaltim.tribunnews.com/2016/01/14/ini-kronologiledakan-bom-di-sarinah-thamrin-dan-starbucks.

15 Syamsul Ma'arif, "Ideologi Pesantren Salaf:Deradikalisasi Agama dan Budaya Damai" 12, no. 2 (2014): 200-201. 
membusukkan nama agama ketika dilakukan dengan mengatasnamakan agama terlebih jika mengatasnamakan agama Islam yang dikenal sebagai agama kasih sayang. ${ }^{16}$

Sedangkan pengertian Pondok Pesantren ialah madrasah dan asrama (tempat mengaji, belajar agama Islam) ${ }^{17}$. Kata ini dapat dimaknai sebagai tempat tinggal atau tempat menginap sebagaimana kata punduq dalam Bahasa Arab yang saat ini dimaknai hotel atau penginapan. Sedangkan kata pesantren sebagaimana dalam Kamus Bahasa Indonesia dimaknai sebagai asrama tempat santri atau tempat murid-murid belajar mengaji dan lain-lain ${ }^{18}$.

Pesantren secara bahasa berasal dari kata santri yang dirangkai dengan awalan pe- dan akhiran -an. Santri sendiri berasal dari bahasa Sansekerta, shastri, yaitu orangorang yang tahu buku-buku suci agama Hindu atau seorang sarjana ahli kitab suci agama Hindu. ${ }^{19}$ Pondok pesantren jika dilihat dari prespektif bahasa merupakan perpaduan dari dua budaya yang berlainan namun mengakar dalam sejarah Nusantara. Pondok pesantren dapat disebut sebagai salah satu model pendidikan Islam yang khas Indonesia.

Kata salaf dalam pengeritan pesantren di Indonesia dapat dipahami dalam makna literal dan sekaligus terminologis khas Indonesia. Secara literal, kata salaf dalam

16 “Surat Al-Anbiya ayat 107," n.d.

17 Nurul Aini, "Pesantren, Organisasi Modern Islam di Masa Penjajahan dalam Darussalam Jurnal Ilmiah Islam dan Sosial (Martapura: Sekolah Tinggi Agama Islam Darussalam)" 8, no. 1 (2009): 47-64.

18 Tim Penyusun Kamus Pusat Bahasa, Kamus Bahasa Indonesia (Jakarta: Pusat Bahasa, 2008), 1170.

19 Zainal Abidin, "Pesantren dan Transformasi Sosial: Memotret Peran Pesantren dalam Pembangunan Masyarakat Madani", dalam Media Nusantara (Bandung: LPPM Universitas Islam Nusantara)," no. 3 (2008): 95-108. 
istilah pesantren adalah kuno, klasik dan tradisional sebagai kebalikan dari pondok modern, kholaf atau ashriyah. Sedangkan secara terminologi sosiologis, pesantren salaf adalah sebuah pesantren yang mengajarkan ilmu-ilmu agama saja kepada para santri. Umumnya, ilmu agama yang diajarkan meliputi Al-Quran, hadits, fikih, akidah, akhlak, sejarah Islam, faraidh (ilmu waris Islam), ilmu falak, ilmu hisab, dan lain-lain. Semua materi pelajaran yang dikaji memakai buku berbahasa Arab yang umum disebut dengan kitab kuning, kitab gundul, kitab klasik atau kitab turats.

Metode belajar mengajar di pesantren salaf biasanya menggunakan metode sorogan wetonan dan metode klasikal. Ciri khas kultural yang terdapat dalam pesantren salaf antara lain; a) Santri lebih hormat dan santun kepada kyai, guru dan seniornya. b) Santri senior tidak melakukan tindak kekerasan pada yuniornya. c) Hukuman atau sanksi yang dilakukan biasanya bersifat non-fisikal seperti dihukum mengaji atau menyapu atau mengepel. d) Memakai sarung dalam keseharian. e) Berafiliasi kultural ke Nahdlatul Ulama (NU) dengan ciri khas seperti fikih bermadzhab Syafi'i, akidah tauhid Asy'ariyah Maturidiyah, tasawuf Al-Ghazali, tarawih 20 rakaat plus 3 rokaat witir pada bulan Ramadan, baca qunut pada shalat Subuh, membaca tahlil pada tiap malam Jum'at, peringatan Maulid Nabi, Isra' Mi'raj. f) Sistem penerimaan tanpa seleksi. g) Setiap santri yang masuk langsung diterima sedangkan penempatan kelas sesuai dengan kemampuan dasar ilmu agama yang dimiliki sebelumnya. h) Biaya masuk pesantren salaf umumnya jauh lebih murah dan itdak ada daftar ulang setiap tahunnya, dan Infrastruktur lebih sederhana.

Santri pesantren salaf memiliki kualitas keilmuan antara lain; a) Menguasai kitab kuning atau literatur klasik Islam dalam bahasa Arab dalam berbagai disiplin ilmu 
agama. b) Menguasai ilmu gramatika bahasa Arab atau Nahwu, Sharaf, balaghah (maany, bayan, badi'), dan mantiq secara mendalam karena ilmu-ilmu tersebut dipelajari serius dan menempati porsi cukup besar dalam kurikulum pesantren salaf di samping fikih madzhab Syafi'i. d) Santri dalam memahami kitab bahasa Arab memakai sistem makna gandul dan makna terjemahan bebas. ${ }^{20}$

\section{Fenomena Pondok Pesantren Miftahul `Ulum}

a. Sejarah Pondok Pesantren Miftaahul 'Uluum

Pondok Pesantren Miftahul Ulum (PPMU) didirikan oleh KH. M. Arba'i Zaini pada tahun 1977. Pondok Pesantren Miftahul Ulum (PPMU) juga dikenal dengan nama Pondok Bandar Agung karena tempatnya berada di kelurahan Bandar Agung, Kecamatan Bandar Sribhawono, Kabupaten Lampung Timur. KH. M. Arba'i Zaini wafat pada tahun 2006, Beliau mengasuh pondok pesantren ini selama hampir 29 tahun. Beliau meninggalkan enam orang anak yaitu: Nyai Mahmudah, Ky. Taukhid, Ky. Khafidz, Ky. Mujahid, Ky. Mahmud dan KH. Muhdir. Setelah KH. M. Arba'i Zaini wafat, Pondok Pesantren Miftahul Ulum (PPMU) diasuh oleh putera keempat beliau yang bernama Ky. Mujahid, dalam menjalankan tugasnya membina dan mengembangkan pondok pesantren, generasi kedua ini beliau dibantu oleh seluruh saudara-saudaranya sampai sekarang. Sejak diangkatnya generasi kedua ini di Pondok Pesantren Miftahul Ulum nilai ke khasan salafnya sama sekali tidak berubah, hal ini dibuktikan dengan berbagai

20 Team Pondok Pesantren Al- Khoirot, "Pesantren Salaf dan Ponpes Salafi," diakses 23 Maret 2016, http://www.alkhoirot.com/beda-pondok-modern-danpesantren-salaf. 
budaya khas pondok pesantren salaf yang masih berdiri kokoh dan kurikulumnya yang masih terasa sangat kental. ${ }^{21}$

\section{b. Tradisi-Tradisi Pondok Pesantren Miftahul Ulum}

Tradisi yang dilakukan, diamalkan, dipelihara dan dilestarikan di pondok pesantren Miftahul Uluum ialah Hubungan antara kiai dan santri sangat erat. Hal ini direalisasikan apabila santri akan pulang harus ijin atau mohon restu kepada kiai. Hubungan santri dengan masyarakat sekitar adalah tetangga, dalam hubungan ini, santri boleh mengikuti kegiatan masyarakat apabila kegiatan itu mendukung tujuan santri datang ke pesantren. Pondok Pesentren Miftahul 'Uluum memiliki beberapa kebiasaan yang dilakukan oleh santri antara lain : 1 . Kebiasaan dalam bentuk ibadah (Sholat jamaah, sholat malam, sholat dhuha, Membaca al-Qur'an, Bentuk-bentuk Riyadhoh, puasa dalail, puasa sunah, zikir dan lain-lain), 2. Kebiasaan sehari-hari (Memasak secara berkelompok, Mencuci perkakas dan pakaian sendiri, Senantiasa memakai sarung, dan peci), 3. Hubungan dengan orang lain (Bersalaman dan mencium tangan kyai, panggilan "kang" untuk santri senior maupun junior), 4. Tradisi mingguan, bulanan, tahunan (Membaca sholawat, tahlilan, ziarah, Istighotsah dan haul).

Dengan adanya berbagai tradisi yang berlaku di dalam pondok pesantren Miftahul 'Uluum, menuntut para santri agar hidup teratur, bersih, disiplin, punya rasa tanggung jawab, suka kebersamaan dan menjauhkan dari sifat individualisme. Kesemuanya itu adalah merupakan salah satu usaha mendidik, membimbing, merealisasikan apa

21 "Observasi, Pondok Pesantren Miftaahul 'Uluum," 1 Februari 2016. 
yang telah diperoleh santri pondok pesantren Miftahul 'Uluum dalam kehidupan sehari-hari. ${ }^{22}$

\section{c. Kurikulum Pondok Pesantren Miftahul Ulum}

Materi yang diajarkan di pondok pesantren Mifathul 'Uluum, mengambil kitab-kitab karangan para ulama yang bermazhab syafi'i, dan untuk dapat memahami kitab kitab tersebut para santri yang duduk pada kategori kelas Ibtida' dibekali dengan materi penguasaan nahwu (tatabahasa), sorof (etimologi), misalnya kitab al-Jurumiah, al-Imriti, dan al-Fiyah serta Amtsilatul Tasrifiyah (sebuah kitab kecil yang membahas dari segi etimologi). Setelah itu santri dituntut untuk menerapkannya dalam pemahaman pada teks-teks kitab klasik yang meliputi fikih, ushul fikih, hadits, tafsir, tasawuf, tauhid serta tarikh.

Pondok Pesantren Miftahul 'Uluum dalam mencirikan salafiyahnya ada beberapa kitab yang secara langsung maupun tidak langsung berisi tentang materi-materi akhlak yang dijadikan materi pembelajaran pendidikan akhlak santri. Kitab yang banyak mengandung materi tentang akhlak yang diajarkan di pondok Pondok Pesantren Miftahul 'Uluum adalah kitab Ta'lim al-Mutta'allim karangan Imam al-Zarnuji yang berisi tentang etika-etika dalam mencari ilmu. Selain kitab Ta'lim al-Muta'allim, juga diajarkan beberapa kitab. Antara lain adalah: Nasoikhul Ibad kitab ini membahas etika beribadah, Bidayatul Hidayah kitab yang berisi tentang etika anak dalam berhubungan dengan Tuhan, manusia dan alam sekitar, kitab ini juga menjelaskan etika terhadap orang tua, Irsyadul Ibad, kitab ini berisi tentang hormat-menghormati antar sesama, Hadits Arbain Matan al-Hadits berisi Hadits tentang keikhlasan niat, keutamaan belajar dan mengajarkan al-Qur'an, menolong tetangga, mengucapkan salam, berbuat baik,

22 Ibid. 
zuhud dan menghormati ulama dan lain-lain, Hadits Riyadh al-Shalihin berisi tentang hukum-hukum fiqih, termasuk muamalah, sifat-sifat terpuji seperti sabar, jujur, muroqobah, istiqomah, saling tolong-menolong, ikhlas, keutamaan prilaku baik, tatakrama, pakaian, salam, zikir dan lain-lain. Selain materi wajib, juga banyak yang mempelajari kitab-kitab yang mengandung unsur materi akhlak seperti, Minhajut Abidin, Ihya Ulumuddin dan lain sebagainya. ${ }^{23}$

\section{Pondok Pesantren Salaf sebagai Model Pendidikan Deradikalisasi Terorisme}

Menurut Sarlito Wirawan pada era moderen saat ini para pelaku terorisme adalah orang-orang biasa yang kebetulan memiliki ideologi yang berbeda, yang sangat meyakini seolah-olah ideologi mereka yang paling benar, di luar itu salah dan merusak umat manusia oleh karenanya harus diperangi. ${ }^{24}$ Ideologi radikal tersebut menurut Fathurin Zen, berakar dari paham dan fanatisme agama atau kepercayaan yang keliru. ${ }^{25}$

Berkenaan dengan permasalahan tersebut, maka perang melawan terorisme tidak bisa dimenangkan hanya dengan cara membunuh dan menangkap teroris, mengumpulkan intelijen atau mengamankan perbatasan, tetapi diperlukan juga perang gagasan yang menjadi sumber dari kekerasan dan terorisme. Dalam kasus yang terjadi di Indonesia, sebagamana juga dikemukakan Irfan Idris, bahwa tindakan represif yang dijalankan oleh Densus 88 meskipun berhasil mengungkap dan menangkap

23 Ibid.

24 Sarlito Wirawan Sarwono, Teroriseme di Indonesia dalam Tunjauan Psikologi (Jakarta: Pustaka Alfabet dan LaKIP, 2012), 16.

${ }^{25}$ Fathurin Zen, Radikalisme Retoris (Jakarta: Bumen Pustaka Emas, 2012), 205. 
berbagai tragedi teror di tanah air. Namun, strategi ini ternyata tidak cukup, oleh karena itu perlu strategi yang lain, yang bersifat soft approach melalui pendekatan deradikalisasi, dan hal ini dapat dilakukan melalui model pendidikan non formal yaitu pondok pesantren. ${ }^{26}$

Pondok Pesantren dengan berbagai variannya dalam sejarah Indonesia dapat ditelusuri keberadaannya sampai Abad ke-13 M sebagai lembaga pendidikan yang berkembang subur di pedesaan dan daerah terpencil. ${ }^{27}$ Terkait asal-muasal terbentuknya lembaga pendidikan Islam ini masih menjadi objek perdebatan dan kajian yang terus berkembang. Perdebatan atau setidakny perbedaan pandangan terjadi antara mereka yang melihat bahwa pondok pesantren merupakan produk asli Indonesia, ${ }^{28}$ mereka yang melihat pondok pesantren sebagai derivasi model pendidikan Hindu di India, ${ }^{2930}$ maupun yang

26 Usman, “Model Deradikalisasi Narapidana Terorisme Studi Perbandingan Deradikalisasi di Yaman, Arab Saudi, Singapura, Mesir dan Indonesia, Jurnal Inovatif" VII, no. 2 (2014): 2.

27 Murdan, "Pondok Pesantren dalam Lintasan Sejarah" dalam Ittihad Jurnal Ilmi: Keagamaan, Pendidikan dan Kemasyarakatan, Vol. 2 No.1 April 2004 (Banjarmasin: Kopertais Wilayah XI Kalimantan)" 2, no. 1 (2004): 33-45.

28 Said Aqil Husein Al-Munawar, "Aktualisai Nilai-nilai Qur'ani dalam Sistem Pendidlk Islam," in Pesantren dan Transformasi Sosial..., ed. oleh Zainal Abidin (Jakarta: Ciputat Press, 2005), 95-108.

29 Nurcholish Madjid, Bilik-bilik Pesantren: Sebuah Potret Perjalanan (Jakarta: Paramadin, 1997); Karel A. Steenbrink, "Pesantren, Madrasah, Sekolah: Pendidikan Islam dan Kun Modern," in Pesantren dan Transform Sosial..., ed. oleh Zainal Abidin (Jakarta: LP3ES, 1983), 95-108.

30Nurcholish Madjid, Bilik-biiik Pesantren: Sebuah Potret Perjalanan (Jakarta: Paramadin, 1997), hal. 3 dan Karel A. Steenbrink, Pesantren, Madrasah, Sekolah: Pendidikan Islam dan Kun 
berpendapat bahwa pra keislaman di Baghdad saat berada dalam puncak keemasan Islam merupakan inspirasi bagi pembentukan lembaga pendidikan Islam di Indonesia saat ini, ${ }^{31}$ Apapun pendapat yang dikemukakan, secara umum pondok pesantren diakui sebagai lembaga yang menjaga tugas mulia dalam penyebarluasan ajaran Islam di Nusantara.

Pondok Pesantren Miftaahul ‘Uluum merupakan salah satu lembaga pendidikan non formal yang ada diwilayah Kabupaten Lampung Timur, tepatnya di Desa Bandar Agung Kecamatan Bandar Sribhawono. Pondok Pesantren Miftaahul 'Uluum ini memiliki peran yang sangat penting di era moderen saat ini, selain sebagai mesin pencetak tameng dari degradasi runtuhnya moral pemuda juga sebagai model pendidikan deradikalisasi terorisme.

Peran Pondok Pesantren Miftaahul 'Uluum sebagai model pendidikan deradikalisasi terorisme ini dapat dilihat dari tradisi-tradisi yang ada di pesantren, dimana sikap gotong royong, menghormati sesama santri dengan panggilan "kang" meskipun santri yang dipanggil tersebut usianya lebih kecil. Hal ini merupakan cerminan dan ajaran yang sebetulnya tanpa disadari oleh para santri membuat mereka menghormati tanpa memandang ras, kasta dan gen orang lain. Selanjutnya ialah pembekalan kepada para santri melalui kajian kitab fiqih, kitab akhlak, kitab tasawuf, kitab taukhid dengan pondasi utamanya kitab nahwu dan sorof yang tentunya mampu membuat pola pikir para santri lebih kompleks terhadap sesuatu yang akan dihadapi.

Modern, Jakarta: LP3ES: 1983), hal. 20, dikutip dalam Zainal Abidin, Pesantren dan Transform Sosial..., hal. 95-108.

${ }^{31}$ Mahmud Yunus, "Sejarah Pendidikan Islam di Indonesia," in Pesantren dan Transformasi Sosial..., ed. oleh Zainal Abidin (Jakarta: Hidakarya Agung, 1996), 95-108. 
Berangkat dari dua hal yakni tradisi-tradisi pesantren yang humanis dan kajian-kajian kitab yang mendalam inilah Pondok Pesantren Miftahul 'Uluum merupakan tipikal pendidikan deradikalisasi terorisme, dimana tradisi yang humanis ini akan memberikan efek pembiasaan penghormatan kepada orang lain secara mutlak yang secara tidak langsung memberikan efek kepada para santri untuk bersikap rendah hati kepada siapapun. Jika demikian tentu sangat relevan jika tradisi ini mampu menjadi media deradikalisasi terorisme, dimana sebetulnya tindakan radikal dan teror ini muncul yang disebabakan salah satunya ialah menganggap bahwa ideologi pelakulah yang paling benar dan ideologi yang dimiliki selain mereka itu dianggap salah, sehingga ideologi selain mereka harus dimusnahkan karena dianggap berbahaya bagi umat manusia. Sebenarnya dari hal sederhana ini kita bisa meraba dengan mata hati kita, bahwa apa yang dilakukan oleh para pelaku tindakan radikal dan teror ini berangkat dari rasa sikap sombong mereka yang menganggap merekalah yang paling benar. Adanya tradisi pesantren yang humanis tentu saja akan mampu membendung ideologi radikal para santri, sehingga akan menjadikannya sebagai insan yang mampu hidup berdampingan dengan orang lain dengan akhlakul karimah yang tinggi.

Selanjutnya program deradikalisasi terorisme yang ada di Pondok Pesantren Miftaahul 'Uluum ini ialah pembekalan melalui berbagai macam kajian kitab khususnya ilmu nahwu dan sorof. Sebab ilmu nahwu dan sorof ini merupakan salah satu syarat mutlak seorang mufasir Al-Qur'an. Ilmu nahwu dan sorof ini mampu menunjukkan makna yang sesungguhnya dari kajian bahasa yang ada di dalam Al-Qur'an. Berkenaan dengan aksi-aksi radikalisme dan terorisme yang marak saat ini, salah satu penyebabnya ialah cara memahami Al-Qur'an yang hanya dilakukan secara tekstual saja, sehingga para 
pelaku tindakan radikal dan teror ini tidak dapat mengambil intisari ataupun maksud asli dari ayat-ayat AlQur'an, yang sesungguhnya kaya akan nilai-nilai kebaikan. Akan tetapi, justru para pelaku tindakan teror ini mendapatkan makna yang sesungguhnya jauh melenceng dari ajaran Islam itu sendiri. Sehingga tatkala pemahaman terhadap ayat Al-Qur'an yang salah ini diakui kebenarannya maka seakan-akan para pelaku tindakan radikal dan teror ini bertindak atas nama kebenaran. Dengan demikian adanya pembekalan berbagai ilmu agama kepada para santri tentu akan menjauhkan kesalahan dalam memahami ayat Al-Qur'an, sehingga munculnya tindakan radikal dan teror yang disebabkan kesalahan dalam memahami Al-Qur'an tidak akan terulang kembali.

\section{Simpulan}

Pondok Pesantren Miftaahul 'Uluum sebagai model pendidikan deradikalisasi terorisme secara garis besar tergambar dari dua aspek sistem yang ada di dalamnya yaitu pertama, tradisi-tradisi humanis yang ada didalamnya yang secara tidak langsung membentuk kepribadian dan akhlak mulia para santri. Kedua, pembekalan ilmu agama yang relevan kepada para santri dengan harapan para santri tidak memahami ayat-ayat al-Qur'an secara tekstual semata, disisi lain kajian-kajian tafsir Al-Qur'an juga diajarkan kepada para santri sebagai modal awal untuk para santri dalam memahami ayat-ayat Al-Qur'an yang bersifat mujmal, sehingga para santri tidak akan terjerumus pada penafsiran ayat Al-Qur'an yang keliru yang dapat membawanya kedalam lembah tindakan radikal dan terorisme[.] 


\section{REFERENSI}

Abidin, Zainal. "Pesantren dan Transformasi Sosial: Memotret Peran Pesantren dalam Pembangunan Masyarakat Madani", dalam Media Nusantara (Bandung: LPPM Universit Islam Nusantara)," no. 3 (2008).

Abimanyu, Bambang. Terror Bom Azhari-Noor Din. Jakarta: Republika, 2006.

Aini, Nurul. "Pesantren, Organisasi Modern Islam di Masa Penjajahan dalam Darussalam Jurnal Ilmiah Islam dan Sosial (Martapura: Sekolah Tinggi Agama Islam Darussalam)" 8, no. 1 (2009).

Alhusaini, Syaikh Abdul Karim. Al-Barzanji. Semarang: Karya Toha Putra, 2003.

Al-Munawar, Said Aqil Husein. "Aktualisai Nilai-nilai Qur'ani dalam Sistem Pendidlk Islam." In Pesantren dan Transformasi Sosial..., diedit oleh Zainal Abidin. Jakarta: Ciputat Press, 2005.

As'ad, Mahrus. "Radikalisme Islam di Indonesia." dipresentasikan pada Seminar International on

Radicalism in Islamic Perspective: Problem and Solution", STAIN Jurai Siwo Metro, 28 September 2015. Azra, Azyumardi. "“Memahami Gejala Fundamentalisme: Jurnal Ulumul Qur'an" IV, no. 3 (1993).

"Contoh Ayat Ini Ialah Surat At Taubah Ayat 5, Ayat 29 dan Al-Maidah Ayat 44," n.d.

Departemen Pendidikan dan Kebudayaan Balai Pustaka. Kamus Besar Bahasa Indonesia. Jakarta: Balai Pustaka, 1989.

Karel A. Steenbrink. "Pesantren, Madrasah, Sekolah: Pendidikan Islam dan Kun Modern,." In Pesantren dan Transform Sosial..., diedit oleh Zainal Abidin. Jakarta: LP3ES, 1983. 
Ma'arif, Syamsul. "Ideologi Pesantren Salaf:Deradikalisasi Agama dan Budaya Damai" 12, no. 2 (2014).

Madjid, Nurcholish. Bilik-biLik Pesantren: Sebuah Potret Perjalanan. Jakarta: Paramadin, 1997.

Murdan. "Pondok Pesantren dalam Lintasan Sejarah" dalam Ittihad Jurnal Ilmi: Keagamaan, Pendidikan dan Kemasyarakatan, Vol. 2 No.1 April 2004 (Banjarmasin: Kopertais Wilayah XI Kalimantan)" 2, no. 1 (2004). Musthofa, Imam. "Pesantren dan deradikalisasi agama." Sarjana Membangun Desa. Diakses 14 Januari 2016. http:/ / mushthava.blogspot.co.id/2012/02/ pesantrendan-deradikalisasi-agama.html.

"Observasi, Pondok Pesantren Miftaahul 'Uluum," 1 Februari 2016.

“Qs. Al-Ahzab Ayat 21," n.d.

"Radikalisme Agama di Jabodetabek \& Jawa Barat: Implikasinya terhadap Jaminan Kebebasan Beragama/Berkeyakinan." Jakarta: Pustaka Masyarakat Stara, 2010.

Rubaidi, A. Radikalisme Islam, Nahdatul Ulama Masa depan Moderatisme Islam di Indonesia. Yogyakarta: Logung Pustaka, 2007.

Sarwono, Sarlito Wirawan. Teroriseme di Indonesia dalam Tunjauan Psikologi. Jakarta: Pustaka Alfabet dan LaKIP, 2012.

"Surat Al-Anbiya ayat 107," n.d.

Team Pondok Pesantren Al- Khoirot. "Pesantren Salaf dan Ponpes Salafi." Diakses 23 Maret 2016. http:/ / www.alkhoirot.com/beda-pondok-moderndan-pesantren-salaf.

Tim Penyusun Kamus Pusat Bahasa. Kamus Bahasa Indonesia. Jakarta: Pusat Bahasa, 2008.

Usman. "Model Deradikalisasi Narapidana Terorisme Studi Perbandingan Deradikalisasi di Yaman, Arab Saudi, 
Singapura, Mesir dan Indonesia, Jurnal Inovatif" VII, no. 2 (2014).

Yunus, Mahmud. "Sejarah Pendidikan Islam di Indonesia." In Pesantren dan Transformasi Sosial..., diedit oleh Zainal Abidin. Jakarta: Hidakarya Agung, 1996.

Zen, Fathurin. Radikalisme Retoris. Jakarta: Bumen Pustaka Emas, 2012.

Diakses

http:// kaltim.tribunnews.com/2016/01/14/inikronologi-ledakan-bom-di-sarinah-thamrin-danstarbucks. 